\title{
14 The demise of Latin as language of science
}

\author{
von einer unverzichtbaren Gemeinsprache zu einem schmückenden Bildungsattribut und \\ schließlich zu einem Anachronismus. \\ 'from an indispensable common language to a decorative educational attribute and finally \\ to an anachronism'.
}

Korenjak (2016: 102)

\$1 The chronological tour of authors and Denkstile in the preceding chapters will now be broken off: from the eighteenth century onward, most important authors no longer wrote in Latin. A comprehensive study of the circumstances of Latin's demise in the sciences and at the universities has yet to be written. ${ }^{1}$ Only selected aspects of a topic that has only been studied for single cases can be presented here, with the goal of finding the major driving forces that led to the use of vernacular tongues in fields where Latin had been the only option for more than a millennium. ${ }^{2}$ At the advent of the printing press, Latin still had a very comfortable lead as the written language of Western Europe. $70 \%$ of all incunabula were written in Latin. ${ }^{3}$ First, Latin's demise in different contexts is studied (\$2); some problems of the change of linguistic medium, which led to a group of three languages taking over Latin's rôle, are then discussed (§3); some reasons for this change are considered (\$§4-8); and finally, an excursus on artificial languages (\$10), a topic that became important precisely when Latin's hegemony was broken, concludes this chapter.

\$2 The transition away from Latin happened at a varying pace in different fields. Broadly speaking, the more supraregional and theoretical the subject matter, the longer Latin remained its medium. ${ }^{4}$ Literature on practical artes that had to be understandable to people who had not studied at universities sometimes already tended to be written in the vernacular in the sixteenth century (see the list below), and quite universally in the seventeenth century, whereas theoretical scientific works were nearly universally written in Latin until the first half of the eighteenth century. Knowledge of Latin was still necessary in most sciences up to at least $1800 .{ }^{5}$ In some branches, such as law, theology, and classical philology, Latin was still the norm in the nineteenth century and occasionally still in use in the

1 See Ogilvie (2015: 273-275).

2 Leonhardt (2013) speaks of a 'Latin millennium' (title of chap. 3).

3 See Korenjak (2016: 18). The next-most-often-used languages were German (10.8\%), Italian (8\%), and French (5.7\%); all others were below $2 \%$.

4 See table in Schiewe (1996: 102). See also Leonhardt (2009/2010).

5 Thus Leonhardt (2013: 197). 
twentieth (see chap. 15 below). ${ }^{6}$ The numbers of scientific book publications at the book fair in Leipzig from 1740 to 1800 are very telling. Whereas the total numbers of books rise very strongly from 12 to 129 publications in the natural sciences, the percentage of Latin plummets: in 1740 the Latin:German ratio is 8:4; in 1800 it is $21: 108{ }^{7}$ Similar dates were observed in another study by Pörksen; he studied the extensive collection of scientific (including natural-scientific, mathematical, and medical) books from the Herzog August Bibliothek (Wolfenbüttel) and published the graphic reprinted as figure 27. It is in the 1770s that the general amount of books 'explodes', most of them being German ones. ${ }^{8}$ Hardly surprisingly, the second half of the eighteenth century sees many theoretical publications for or against the use of Latin in science and education, for instance Bernhard Stöger, Über die Frage: Welcher Lehrvortrag in der Philosophie ist auf deutschen Universitäten der nützlichere: Der lateinische od. der deutsche? ('On the Question: Which Lecture Language in Philosophy Is More Useful at German Universities: Latin or German?'; Salzburg, 1790), ${ }^{9}$ who opts for German, and the response, over twice as long, by the Benedictine Aemilian Würth, Frage: Welcher Lehrvortrag in der Philosophie der nützlichere? ('Question: Which Lecture Language in Philosophy Is the More Useful?'; Augsburg, 1793). ${ }^{10}$ Stöger argues that the Germans should follow the French and English and use their native tongue, while Würth stresses Latin's precision and stability, but, tellingly, writes in German too.

In many other fields and regions, Latin had already lost its hegemony in the sixteenth century; for instance, poets in France change from predominantly Latin to predominantly French toward the end of the sixteenth century. ${ }^{11}$ The general situation on the book market is similar in France: French already overtook Latin around 1560, after which Latin stayed at around a quarter of French book publications for the next century. Similar changes happen in Italy only nearly a century later. ${ }^{12}$ Things were, however, different in matters of science and learning, where international communication was vital and a precise linguistic vehicle was needed. In the middle of the seventeenth century, Blaise Pascal still changes to Latin as soon as he talks about scientific matters (here on combinatorics to Fermat, letter from 29 July 1654, ed. in About 1983: 41): 'Par exemple, et je vous le dirai en latin, car le français n'y vaut rien: Si quotlibet litterarum, verbi gratia octo

6 The rôle of language at German universities is studied by Schiewe (1996: 80-115).

7 As can be seen from the table in Pörksen (1986: 50).

8 A similar date is confirmed by Waquet (1998: 113-114).

9 Online at http://mdz-nbn-resolving.de/urn:nbn:de:bvb:12-bsb10840617-0.

10 Online at http://mdz-nbn-resolving.de/urn:nbn:de:bvb:12-bsb10047374-7.

11 See statistics in Ford (2013: chap. 1).

12 Numbers collected in Waquet (1998: 102-103). 
[...]' ('For example, and I'll tell you this in Latin, because French is no good for it: Si quotlibet litterarum, verbi gratia octo [...]').

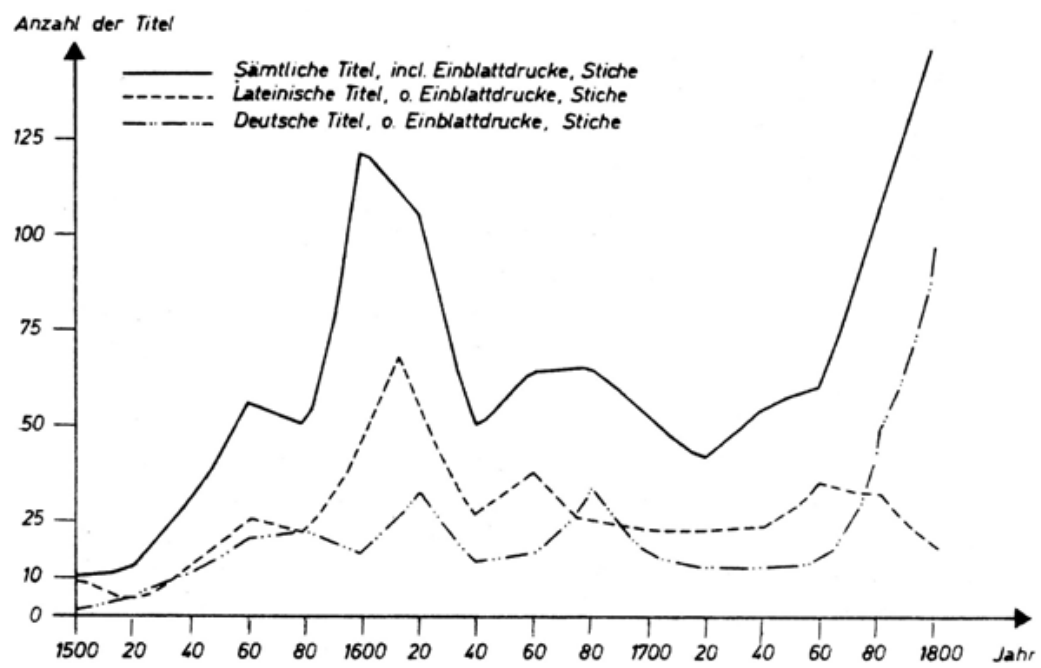

Fig. 27: Latin vs German books at twenty-year intervals in the Wolfenbüttel library. A definite trend against Latin does not begin until 1770. Source: Pörksen (1986: 55).

A century later, in 1765, Latin was still perceived as the international language of erudition by Diderot's Encyclopédie, even though the work is written in French (Diderot, s.v. langue): ${ }^{13}$

La langue latine est d'une nécessité indispensable, c'est celle de l'église catholique, \& de toutes les écoles de la chrétienté, tant pour la Philosophie \& la Théologie, que pour la Jurisprudence \& la Médecine: c'est d'ailleurs, \& pour cette raison même, la langue commune de tous les savans de l'Europe, \& dont il seroit à souhaiter peut-être que l'usage devint encore plus général \& plus étendu, afin de faciliter davantage la communication des lumieres respectives des diverses nations qui cultivent aujourd'hui les sciences: car combien d'ouvrages excellens en tous genres de la connoissance desquels on est privé, faute d'entendre les langues dans lesquelles ils sont écrits?

'The Latin language is an indispensable necessity: it is the language of the Catholic Church, and of all schools of Christianity, as much for philosophy and theology as for jurisprudence and medicine. It is, moreover, and for this very reason, the common language of all scholars of Europe, the use of which it is perhaps to be hoped will become even more general and more widespread, in order to facilitate further the communication of the respective luminaries of the various nations which today cultivate the sciences. For how many excellent

13 Further similar statements from all over Europe in the eighteenth century can be found in Waquet (1998: 101-102). 
works of all kinds are there of whose acquaintance one is deprived for lack of understanding the languages in which they are written?'

The standard work on Latin's use in early modern society (especially but not only in France) is Françoise Waquet's Le latin ou l'empire d'un signe (1998). She shows in the first part in a very detailed manner how the rôle Latin played in school curricula started to change in the seventeenth century - for the first time allowing space for the mother tongue, here French, to be taught and studied - and around the middle of the eighteenth century, when Latin stopped being the most important subject in many schools. Of course, Latin had been taught actively and passively, and in most schools up to that time pupils were supposed to speak Latin not only in class but also with one another. This background makes it easy to estimate that active command of the Latin language was a matter of course for educated people up to the eighteenth century - at least as much as is now the case for English among non-native natural scientists. The emphasis put on Latin in higher schools fluctuated in the eighteenth and nineteenth centuries but generally remained high. It was only in 1882 that a baccalauréat without Latin became possible for the first time (Waquet 1998: 25). Nevertheless, there seems to have been a growing gap between school Latin and 'real life', such that in the eighteenth and nineteenth centuries most important scientific contributions were already published in the vernacular. Before the opening of this gap, difficulties in the active use of Latin could only be an obstacle for people who had not studied at a 'decent' school (such as some technical writers from artisan families); other people who instead chose to use their vernacular for publications will have done so for other reasons. A short list of some early vernacular scientific publications may help to identify motivations.

- (Alternative) medicine: Theophrastus Paracelsus, German inaugural lecture in Basle, 1528 (caused a stir). ${ }^{14}$

- Ballistics: Niccolò Tartaglia, La nova scientia (Vinegia [Venice], 1537), in Italian. The new science is ballistics; the treatise is mostly concerned with practical applications.

- Mathematics: Simon Stevinus, De Thiende ('On Decimal Fractions'; Leyden, 1585), in Dutch. Stevinus was convinced that Dutch was most suited for science and invented many Dutch scientific terms. ${ }^{15}$

14 Anti-humanism and an alternative, not tradition-bound approach to medicine seem to have been his reasons for doing this. See Pörksen (1994a); for his biography, still Rádl (1913).

15 See Vanden Berghe et al. (2004). 
- Heliocentricism: Galileo Galilei, Dialogo sopra i due massimi sistemi del mondo (Fiorenza, 1632), in Italian. Intended for a wider Italian public.

- Scientific methodology: René Descartes, Discours de la méthode pour bien conduire sa raison et chercher la vérité dans les sciences (La Haye, 1637), in French.

- Foundation of the Royal Society of London for Improving Natural Knowledge in 1660. It published mostly in English. ${ }^{16}$

- Microbiology: Robert Hooke, Micrographia (London, 1665), in English. Discovery of microorganisms.

- Chemistry: Robert Boyle, The Sceptical Chymist (London, 1666), in English. Foundation of modern chemistry.

- Foundation of the Académie royale des sciences in 1666, publishing mostly in French.

- The jurist Christian Thomasius starts to lecture in German in Leipzig in 1687.

- Optics: Isaac Newton, Opticks (London, 1704), in English, in contrast to his Principia, first published in Latin. ${ }^{17}$ But the second edition was published in Latin as Optice (Londini, 1706).

It was in the time around 1660 that scientific institutions such as the Royal Society or the Académie royale, which often published in their vernaculars, were established for the first time. ${ }^{18}$ Interestingly, the Royal Society excluded human sciences and theology in order not to get caught up in Reformation quarrels. It is tempting to see this as the germ of the later special development of the English term 'science' as applying only to the natural sciences (as discussed in chap. 1), although this may be oversimplifying things - at any rate, similar societies on the Continent worked in both natural and human sciences.

On the whole, it would seem that Latin retained a near-monopoly in science until the first quarter of the seventeenth century. Many of the early works in the list above were more of practical or regional interest. A list of crucial scientific works in French in the eighteenth century would certainly be longer than a corresponding one of Latin ones. Nonetheless, for the rest of the seventeenth and the beginning of the eighteenth century important works of more than regional interest tended to be translated into Latin quickly and had often greater success in Lat-

16 In contrast, the Acta eruditorum (Leipzig) were published in Latin until 1776: http://www. izwtalt.uni-wuppertal.de/Acta.html.

17 For a more extensive list of authors and their publication languages, see Pörksen (1986: 6061).

18 The importance of these societies for the new kind of modern science has often been stressed, e.g. by Teich (2015: 54-63). 
in with an international audience. ${ }^{19}$ The scientific journals can be seen as a foreboding of Latin's eventual demise as the international language of learning. But at first there were sometimes (unofficial) Latin translations, for example for the Royal Society's Philosophical Transactions. ${ }^{20}$ Most French scientists in the later seventeenth century already published exclusively in French (e.g. Edme Mariotte, Bernard Le Bovier de Fontenelle; René Descartes, Blaise Pascal for the greater part), whereas in English this would only be the case in the eighteenth century (Stephen Hales, John Priestly) and in German around its middle, as can be seen from the graphic above. In Italian, Galileo and Bruno are better seen as exceptions with their early use of the vernacular, and their intention was polemical: they wanted to reach a larger, not only academic, audience within Italy. They both published their more scientific or technical works in Latin.

It will have become clear by now that the trend that led to Latin's replacement originated in France in the later seventeenth century. The reason for the French language's success would seem to be its new ideals and its function as a rôle model for style, which led to French becoming the international language ${ }^{21}$ in many other areas around the same time, most prominently in diplomacy: the Treaty of Rastatt (1714) was in French only and can be seen as the definite turning point. In 1698 Jean-Baptiste du Hamel still used Latin because ${ }^{22}$

linguam Gallicam non esse tam late fusam quam Latinam, quae ubique gentium eadem est, neque tot mutationibus obnoxia, quot linguae vulgares.

'the French language is not as widely used as the Latin one, which is the same for all peoples and is not prone to as many changes as the vulgar tongues'.

By 1751 the outcome had become clear, and D'Alembert concedes: ${ }^{23}$

L'usage de tout écrire aujourd'hui en langue vulgaire, a contribué sans doute à fortifier ce préjugé, et peut-être est plus pernicieux que le préjugé même. Notre langue s'étant répandue par toute l'Europe, nous avons cru qu'il était temps de la substituer à la langue latine, qui,

19 For instance, Immanuel Kant's critiques were quickly translated by Friedrich Gottlob Born as Opera ad philosophiam criticam, 3 vols (Lipsiae, 1796-1798). For more examples, see Waquet (1998: 108-109).

20 See Korenjak (2016: 239).

21 See Fumaroli (2003), who presents examples of non-French authors writing in French between 1714 and 1814. Disappointingly, his 'livre n'a pas la moindre prétention de théoriser, ni de défendre une thèse quelconque' ('book does not claim to theorise or defend any thesis whatsoever'; 24).

22 Regiae Scientiarum Academiae historia (Paris: Etienne Michalet, 1698), unpaginated preface. Quoted from Gordin (2015b: 42).

23 D'Alembert ([1751] 1911), http://art-bin.com/art/oalembert2.html. 
depuis la renaissance des lettres, était celle de nos savants. [...] Cependant il résulte de là un inconvénient que nous aurions dû prévoir. Les savants des autres nations, à qui nous avons donné l'exemple, ont cru avec raison qu'ils écriraient encore mieux dans leur langue que dans la nôtre. L'Angleterre nous a donc imités; l'Allemagne où le latin semblait s'être réfugié, commence insensiblement à en perdre l'usage; je ne doute pas qu'elle ne soit bientôt suivie par les Suédois, les Danois et les Russes. Ainsi, avant la fin du dix-huitième siècle, un philosophe qui voudra s'instruire à fond des découvertes de ses prédécesseurs, sera contraint de charger sa mémoire de sept à huit langues différentes, et, après avoir consumé à les apprendre le temps le plus précieux de sa vie, il mourra avant de commencer à s'instruire. L'usage de la langue latine, dont nous avons fait voir le ridicule dans les matières de goût, ne pourrait être que très utile dans les ouvrages de philosophie dont la clarté et la précision doivent faire tout le mérite et qui n'ont besoin que d'une langue universelle et de convention. Il serait donc à souhaiter qu'on rétablît cet usage; mais il n’y a pas lieu de l'espérer. 'The practice of writing everything today in the vernacular has undoubtedly contributed to strengthening this prejudice, and is perhaps more pernicious than the prejudice itself. As our language [French] has spread throughout Europe, we thought it was time to replace the Latin language with it, which, since the renaissance of letters, had been the language of our scholars. [...] However, this produces a disadvantage that we should have foreseen. The scholars of other nations, to whom we set an example, rightly believed that they would write even better in their own language than in ours. England has therefore imitated us; Germany, where Latin seemed to have taken refuge, is slowly beginning to lose the use of it. I have no doubt that it will soon be followed by the Swedes, the Danes, and the Russians. Thus, before the end of the eighteenth century, a philosopher who wants to learn in depth the discoveries of his predecessors will be forced to load his memory with seven or eight different languages, and, having spent the most precious time of his life learning them, he will die before he begins to learn their philosophy. The use of the Latin language, the ridiculousness of which we have shown in matters of taste [i.e. in the belles-lettres], could only be very useful in works of philosophy, where clarity and precision must take all the credit, and which only require a universal and conventional language. It would therefore be to be wished that this use would be re-established, but there is no reason for hope.'

This is quite a surprising and far-sighted confession by the author of a huge and very influential encyclopaedia written in French, not in Latin. Others, such as Pierre Louis de Maupertuis, tried to devise schemes to return to a Latin using European elites (de Maupertuis 1752: 57-58):

Il ne faudroit que confiner dans une même Ville, tout le Latin de son Païs; ordonner qu'on ny prechât, qu'on n'y plaidât, qu'on n'y jouât la Comedie qu'en Latin. Je crois bien que le Latin qu'on y parleroit ne seroit pas celui de la Cour d'Auguste, mais aussi ce ne seroit pas celui des Polonois. Et la jeunesse qui viendroit de bien des Païs de l'Europe dans cette Ville, y apprendroit dans un an plus de Latin qu'elle n'en apprend dans cinq ou six ans dans les Collèges.

'One would only have to confine in the same city all the Latin of one's country; to order that there people preach, plead, and play the comedy exclusively in Latin. I well believe that the Latin spoken there would not be the Latin of the court of Augustus, but it would also not be 
the Latin of the Poles. And the youth who'd come from many countries of Europe to this city would learn more Latin in a year's time than they learn in five or six years' time in the colleges.'

But most less far-sighted compatriots of D'Alembert and Maupertuis did not see the problem, and conferred immortality on the most perfect French language (see $\S 6$ below).

The list at the beginning of the next chapter will show that Latin still played an important rôle in the sciences in countries beyond the direct influence of French, English, and German all through the eighteenth and well into the nineteenth century. Then, some writers start to complain both about French as the new language of science, such as Johann Rudolf Kiesling, who in 1752 called it a morbus epidemicus, ${ }^{24}$ and the problem that scientists will have to learn many languages without the unifying Latin: like D’Alembert, Albrecht von Haller bemoans that it will be necessary to learn 'six or eight' languages. ${ }^{25}$

\$3 The actual linguistic transition from Latin to the vernacular languages was, of course, easiest for the Romance languages. The French could and very often did just change a term's ending and pronounced it as if it was a proper French word. ${ }^{26}$ The fact that French is syntactically less versatile than Latin will not have been too great a problem: instead of, say, an ablativus absolutus, a subordinate clause might do. The same is true for Italian and largely also for English, which had already become a kind of Germanic-Romance creole in Middle English times. But in the case of German, things were rather more complicated. The language belongs to a different branch of the Indo-European family from Latin, and Germans were not very fond of using foreign terminology. Therefore, many new terms had to be invented. Incidentally, this may also be part of the reason why the transition to the vernacular in science happened later in German. Gottfried Wilhelm Leibniz (1646-1716) and Christian Wolff (1679-1754) ${ }^{27}$ were the most important men in defining the German philosophical and general scientific terminology, which had to

24 Kiesling, Commentatio. Full quotation: Invaluit nostro saeculo morbus, ut rei medicae doctores loqui amant, epidemicus, quo linguae imprimis Gallicae usus eruditis maxime sit familiaris ('In our century, an epidemic disease has grown strong - as the medical doctors choose to call it - by which first of all the use of the French language has become most familiar to scholars'; quoted from Sacré 2014: 18-19).

25 Krebs (2005: 368). More examples can be found in Sacré (2014).

26 Examples in the list in chap. $23 \S 3$ below.

27 See Baumeister, Philosophia definitiva, a lexicon of Wolff's Latin terminology; and for his German terminology Meissner (1737). 
correspond to the existing Latin terminology. Indeed, Wolff (1734) usually offers a Latin translation in his lexicon of German mathematical terms, such as 'Abschnitts-Winkel, Angulus segmenti' (8) to make himself understood. In his Vernünftige Gedancken von Gott (1738), he even offers a German-Latin glossary ${ }^{28}$ of German terms he chose to use for widespread philosophical concepts. Many of these expressions stuck in the German language, but some others did not, as some random examples show:

Vernunfft: ratio,

Versuche: experimenta,

Vor sich bestehendes Ding: substantia,

Zufällige Namen: adjectiva.

Despite such preparatory work, the rôle of Latin remained important in Germany throughout the eighteenth and nineteenth centuries: the German gymnasium grew out of the Philanthropinismus and Humanismus movements, which were at odds in many things but agreed in stressing the importance of Latin, the former more its actual use and the latter more for reading the classics. In a ten-year plan for weekly teaching at the gymnasium from $1816,{ }^{29}$ Latin is still by far the most extensively taught subject: on average 7.6 hours per week (German only 4.4, Greek 5, mathematics 6). In the 1882 Lehrplan by Hermann Bonitz, ${ }^{30}$ Latin even reached an average of 8.2 hours per week; German was down to 2.3, mathematics to 3.7, and Greek to $4.4 .^{31}$ At this time, there were already reformers who strove to abolish Latin composition from the curriculum, but they only succeeded in $1892 .{ }^{32}$ By 1925 Latin had lost its hegemony; in 1938 - in the Third Reich, the Nazis obviously preferring German over Latin - it became close to irrelevant. Despite this slow development, German already became an important vehicle for science in the early nineteenth century. Indeed, English and German followed the French trend and were in the eighteenth and nineteenth centuries able to end the brief sole hegemony of French both in the sciences and in society at large. Throughout this time, French, German, and English remain the three languages of science. ${ }^{33}$ In some fields, for instance in classical studies, this situation remains relatively un-

28 On the five unpaginated pages after p. 672. The first edition (1724) did not contain this appendix.

29 Numbers from Fuhrmann (2001: 149).

30 The same Bonitz who authored the still-indispensable Index Aristotelicus.

31 The Gymnasium was now a nine-year course, at the beginning of the century a ten-year course. Figures from Fuhrmann (2001: 174).

32 Fuhrmann (2001: 219).

33 The 'triumvirate', as Gordin calls this constellation. 
challenged to this day (including Italian as a fourth option). As D'Alembert had predicted, by the later nineteenth century, several other languages aspired to become part of the illustrious group of 'scientific languages'; the case of Russian and its difficult and ultimately successful struggle to reach this goal is described admirably by Gordin (2015b: chaps 2-3). Indeed, the only distantly related Russian language had to adapt and standardise in a very similar way to German when taking over the rôle of Latin, and to Latin when taking over the rôle of Greek. Scientific Russian borrowed much from the then leading German (as did the Russian language in general). Some considerations of this language's structure will be presented in chapter 23 in comparison to others. Other languages, excepting further Romance ones such as Spanish, and possibly Japanese, have had at best very limited success so far.

It may be attributed to the events around the two World Wars that English started to take on the rôle of the sole language of science. Savory wrote in 1953: 'English shows signs of becoming the language of science' (153). Around the same time, the arachnologist Reginald F. Lawrence made a survey of the languages used in the Zoological Record from 1865 onward. ${ }^{34}$ English, French, and German, followed by Spanish and Russian, together made up about $90 \%$ of all publications. Toward the end of the period studied by him, English started to rise sharply and only Spanish was able to hold its ground. In the last few decades, it seems that at least in natural science we are again approaching a time of monolingualism, in this case one of English. The reasons for this change are clearly political: the victory of the US and the UK in World War II, and more recently the fall of the Soviet Union. It remains to be seen for how long this situation will remain stable in a world of a booming Asia and a stagnating West. But returning to the question of the reasons for Latin being supplanted in the eighteenth century, a few arguments will now be considered, often already used by contemporaries, and weighed in their importance.

\section{(i) Novelty and adaptability}

\$4 In some cases, a conscious effort not to be part of the scholastic establishment can be sensed. This seems especially obvious among the Italian authors of the sixteenth and early seventeenth century. Christian Thomasius can be mentioned as a later example; he wanted to part with the use of Latin in order to get rid of oldfashioned ways of thinking and the influence of Pfaffen (pejorative German term

34 Non vidi; discussed in Savory (1953: 155-157). 
for priests). ${ }^{35}$ But this reason was certainly not the main one for the development away from Latin; in fact, scientists quite often complain to one another that they cannot read one another's vernacular publications (such as Kepler to Galileo; see chap. 13 §4). The Latin language proved itself to be quite adaptable to new ideas of scholasticism, although classicising humanists who got the upper hand at the gymnasia did their best to petrify the language. Thus one had to choose between a versatile but 'ugly' Latin (the type mostly used) and a beautiful but hardly adaptable and hard to learn variant of the same language (advocated by Ciceronians from at least the fifteenth century onward). The downside of the flexibility of the vulgar tongues is, of course, that they change fast. Even a German native speaker today will find Kant's German difficult and unfamiliar, whereas a Latin reader will move with comparative linguistic ease through the centuries. This will be elaborated below (chap. 16). The following topic is related to it.

\section{(ii) Ease of expression}

\$5 One might also argue that new concepts are more easily expressed in one's native language and not a long-'dead' (see chap. $16 \$ 1$ below) one, an argument often heard in Romanticism. It has, however, already been mentioned that this argument holds true only for people who did not enjoy a thorough education: up to the later nineteenth century, gymnasia were so much focused on Latin that this language will have become like a second native tongue to students. The forgotten world of Latin Jesuit schools in the twentieth century will be discussed below; they will confirm that fluency in Latin cannot have been a problem for scientists who had attended higher education in the centuries before. Yet this faulty argument was very commonly used against Latin in the eighteenth century, for instance by Voltaire, who states in his éloge for the recently deceased Émilie du Chastelet, the French translator of Newton's Principia (Voltaire 1752: 141):

Le français qui est la langue courante de l'Europe, \& qui s'est enrichi de toutes ces expressions nouvelles \& nécessaires, est beaucoup plus propre que le latin à répandre dans le monde toutes ces connaissances nouvelles.

'French, which is the common language of Europe, and which has been enriched with all these new and necessary expressions, is much more appropriate than Latin for spreading all this new knowledge throughout the world.'

The preceding paragraph, and the fact that scholastics had expressed completely new and rich ideas with ease in Latin for centuries, will be enough to convince the

35 Examples are given in von Düffel's edition (= Thomasius 1970). 
reader that Voltaire is here merely voicing propaganda for the glorious and immortal French language. This leads us to political aspects, which are certainly much more crucial in the demise of Latin.

\section{(iii) Nationalism and hegemonic politics}

\$6 The two points just mentioned suggest that it was more a matter of will than of ability which language, the vernacular or the international Latin, was chosen, especially if the vernacular was not too different from the standard language (as in Romance and English), so Latin can be used as a quarry as well as the other way round. Some political changes were favourable for the spread of the use of French in this time. The cancellation of the Edict of Nantes (1685) forced French Protestants to emigrate - together with their language. The outcome of the War of the Spanish Succession (1701-1714) brought a strengthening of France and a weakening of her main competitors (especially the Netherlands, Spain, and Germany). Thus, Englishmen, Germans, and Dutchmen were in general more proficient in French than vice versa around 1700. That the final breakthrough for the French language happened only after the War of the Spanish Succession can be guessed from the fact that Newton's Opticks were quickly translated into Latin in 1706, but into French only in 1720. By then there was a clear feeling among French intellectuals that their language was superior to others. Below (chap. $24 \S 4$ ), a few examples show that such feelings regarding the superiority of one's own language were common also outside of France. The difference with French is that the rest of Europe gradually started to agree; thus, the German Christian Thomasius praises the new French lifestyle, which was quickly becoming the rôle model toward the end of the seventeenth century with its concepts of honnêteté, bel esprit, bon goût, and galanterie. ${ }^{36}$ Frederick II's Königlich-Preußische Akademie der Wissenschaften, located in Berlin, published exclusively in French during the time de Maupertuis led it (1746-1759). ${ }^{37}$ The Berlin academy ran a competition in 1783 on the question: 'Qu'est-ce qui a rendu la langue Française universelle? Pourquoi mérite-t-elle cette prérogative? Est-il à présumer qu'elle la conserve?' ('What made the French language universal? Why does it deserve this prerogative? Is it likely to retain it?'). The winner, de Rivarol, produced 'insights' of the following kind: ‘Ce qui n'est pas clair n'est pas français; ce qui n'est pas clair est encore anglais, italien, grec ou latin' ('What is not clear is not French; what is not clear is still English, Italian, Greek, or Latin'; [1784] 1991: 27). His answers to the questions are,

36 Thomasius (1970: 45).

37 For this paragraph, see Terrall (2017). 
in short, 'because of its inherent superiority' (for the first two) and 'yes' (third question). ${ }^{38}$ This fanatic French nationalism could, of course, not go unanswered. Soon the English and then the Germans entered the struggle for the leading language in Europe in general and thus also for the sciences. As a 'triumvirate', all three languages were important throughout the nineteenth century. After the World Wars, it was the American lifestyle that became similarly 'in', 'hip', and 'cool' in Europe, and since then there has been a steady growth in the percentage of scientific communication in English.

After a language attains a certain hegemony, it is mere pragmatism on the part of authors to make use of the leading language; nationalism is no longer a key component. But initially, nationalism was certainly one of the strongest forces in the choice of scientific language; it was strongly opposed to the shared Latin in the eighteenth century - not only in France, but the French won the battle for the new international language, at least for a few decades. Once the age of nationalism had commenced, changes in the language of university communication became purely politically based, and a reduction of student mobility followed suit. $^{39}$

\section{(iv) Formalisation}

\$7 As has been shown, the New Science entailed more mathematics and formalisation in general and, on the other hand, an attempt to depend less on specific languages, ${ }^{40}$ which in turn makes scientific insight less dependent on the language it was first expressed in. We have seen (chap. 13 §4) that for Galileo geometry is the language of God, not Hebrew, Greek, or Latin, the 'holy' languages of the Middle Ages and early modernity. ${ }^{41}$ This thought is developed further by Étienne Bonnot de Condillac (1714-1780), whose famous dictum is: 'la science est une langue bien faite' ('science is a well-made language'; 1798: 7). Unlike for de Rivarol,

38 Speaking of the European empires and monarchies of his day, de Rivarol claims: 'On ne peut en prévoir la fin, et cependant la langue française doit encore lui survivre' ('One cannot foresee their end, and yet the French language will still have to survive them'; 1784: 38). This was about a decade before the French Revolution! In fact, Rivarol can be seen as a prime example of decadent and arrogant French intellectuals before the Revolution.

39 Summary and further literature in Prinz (2019).

40 See Ulbrich (2009/2010).

41 Isidore, Etymologiae IX.1.3, ed. Reydellet, p. 33, says: Tres sunt autem linguae sacrae: hebrea, greca, latina, quae toto orbe maxime excellunt. His enim tribus linguis super crucem Domini a Pilato fuit causa eius scripta ('There are three sacred languages: Hebrew, Greek, Latin, which excel in the whole world. For on the Lord's Cross His cause [of being executed] was written by Pilate in these three languages'). This is often quoted by later authors. 
such a language is not French - perfect by its divine nature - but formalised, mathematical language. Condillac's prime example is algebra and mathematical formalism in general. Will such a well-made language, then, abolish Latin? It is certainly incorrect to claim that 'the main victim of the Scientific Revolution of the 16th and 17th centuries is without doubt the Latin language and its (quasi)monopoly as the language of academic scientific teaching and publication', ${ }^{42}$ as will have become evident by looking at the major works of this Scientific Revolution and their language in the list above. But the increasing formalisation seems to be the deeper reason making such a statement understandable. These Latin-writing scientists and their more formal approaches eased the way to switch languages.

Indeed, students of most natural sciences today need to learn new formal languages that are no one's native tongue. They all use their own specific systems of symbolic notation. Since the time of much greater and conscious formalisation in the seventeenth century, the importance of the accompanying language has gradually diminished. Modern mathematicians without a common language, I am told by colleagues, are able to 'talk' about mathematics at quite a high level simply using formulas. Other obvious modern examples of such very successful formalised notations would be modern chemistry or logic. Typical modern scientific 'statements' may look like this: ${ }^{43}$

$f(z)=\sum_{k=0}^{n} a_{k} \cdot z^{k}=a_{n} \cdot \prod_{i=1}^{n}\left(z-z_{i}\right)$ in $\mathbb{C}$ or $\mathrm{NaCl}+\mathrm{H}_{2} \mathrm{O} \rightarrow \mathrm{HCl}(\mathrm{aq})+\mathrm{NaOH}(\mathrm{aq})$

Both these statements could also be formulated in a long and complicated sentence in human language, but the formulas are much more concise and succinct for the specialist. The task of the natural languages used in such highly formalised sciences is now much simpler: they mainly explain the constituents of the formulas which are at the core. The roots of this trend of formalisation are, however, much older than the seventeenth century, at least in mathematics. For instance, the first use of our familiar symbols for elementary algebraic operations $(+,-, \times$, $\div$ ) occurs among Italian mathematicians in the fifteenth century. ${ }^{44}$ Formalisation proceeded - and proceeds - at very different paces in different scientific fields.

Another, much more recent example of how all of a sudden there can be a solution to formalising something that had posed linguistic problems for a long time

42 As claimed by IJsewijn (1990-1998: 2:324).

43 Representing, respectively, the fundamental theorem of algebra and the solution of common salt in water.

44 See Cajori (1928-1930); Wolfram (2000). 
are names of colours. Below (chap. 21 §3), it will be seen that medical authors used unusual colour adjectives in Latin, apparently because the usual ones did not seem to be sufficiently precise. Only in Internet times has a consensus been formed to use hexadecimal codes to identify colours: two hexadecimal numbers each indicating the red, green, and blue content of a colour. Thus, instead of a hard-to-translate term such as 'medium aquamarine', one can now identify this colour as '\#66CDAA'. Over sixteen million colours can be defined in this way, something no natural language would be able to do. In order to visualise the quoted colour, for instance, it suffices to enter the code in Google search or in software such as GIMP.

Other, mostly human, sciences have not become strongly formalised and are still much more dependent on the language their texts are written in. ${ }^{45}$ Of course, in any science, there will always remain parts that are not formalised and have to be communicated in 'enhanced' natural language. Even for the formulas quoted above, someone has to tell you in human language what, for instance, ' $\mathrm{HCl}$ ' means.

\section{(v) Illustrations and other extra-linguistic devices}

\$8 First evidence of scientific illustrations can already be found in Aristotle, $D e$

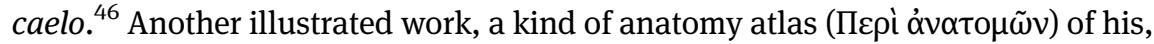
is unfortunately lost. The important rôle of the diagrams in Euclid's Elementa will be seen below (chap. 22 \$4). Other symbolic letter systems already evolved in Hellenistic times, such as the symbols used in textual criticism or music; ${ }^{47}$ in other sciences such as astronomy and geography, maps were of great importance, ${ }^{48}$ and herbals also often depicted the plants they treated. The Vienna Dioscurides from ca. AD 515 is the only complete illustrated scientific manuscript from Antiquity that is still extant (fig. 28). Such manuscripts were certainly not too rare in Antiquity. However, in the history of transmission, such extra-linguistic devices tended to suffer more easily, as scribes were not familiar with them. Illustrations

45 Chap. 22 below will contrast a natural and a human science and their relation to language, with some examples.

46 Stückelberger (1994: 12-16), with reproductions from Aristotle manuscripts. On scientific illustrations, see Weitzmann (1959), and more recently Lazaris (2017) for Byzantine scientific and technical manuscripts. Lazaris is preparing a similar study for Latin manuscripts. For the time between Boethius and Lullus, see Guerrini (2016), including reproductions of many examples.

47 See Netz (1999: 61), with further references; for examples of (now lost) illustrations from Aristotle, see Fögen (2009: 53).

48 Cf. the colour plates in Stückelberger (1994: after 72). 
may have been quite frequent in books in Antiquity but through copying often suffered heavy change, or may have been left off completely, such as the sketches originally included in Vitruvius. Euclid's Elementa are an exception insofar as the diagrams were an indispensable part of the text and were copied in an amazingly uniform way in most manuscripts. In general, diagrams are not rare and are important in many fields in the Middle Ages, both scientific and otherwise. ${ }^{49}$

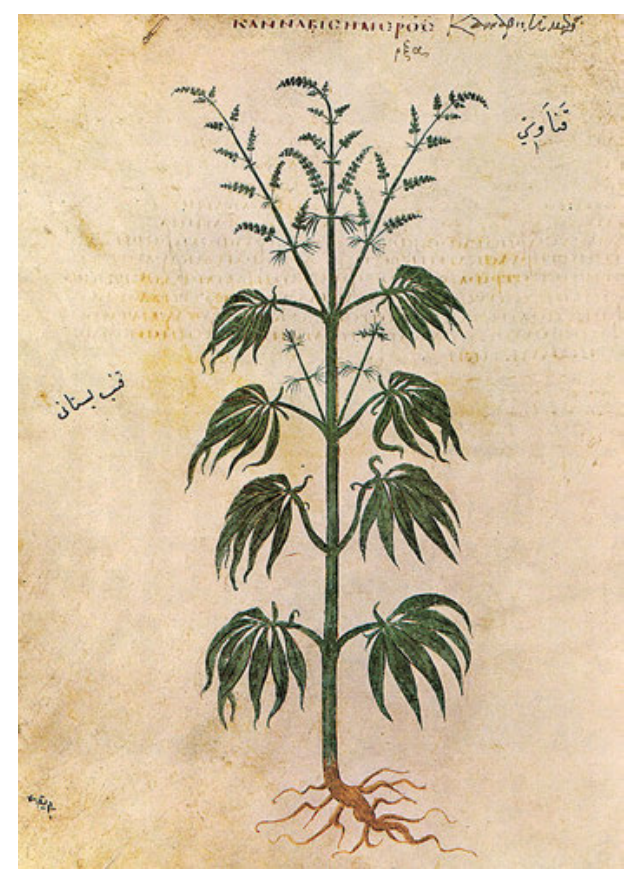

Fig. 28: The Vienna Dioscurides in Greek, Wien, ÖNB, Cod. med. gr. 1, fol. 167v, showing Cannabis sativa. The Arabic gloss reads qinnab bustāni ('garden hemp').

Source: https://commons.wikimedia.org/wiki/File:Cannabissativadior.jpg (image by user Nina-no, public domain).

The advent of the printing press was a great change for such extra-linguistic communication between author and reader..$^{50}$ Only a few years after Gutenberg's invention of movable type, woodcuts started to be used to illustrate books. ${ }^{51}$ In the

49 They were studied by Guerrini (2016) for the mystic Joachim of Fiore. She sees continuities with Raimundus Lullus, who often used diagrams (see chap. $12 \S 5$ above). The rôle of diagrams in geometry and astronomy is studied in Acerbi (2020).

50 On such aids, see Korenjak (2016: 240).

51 Albrecht Pfister in Bamberg seems to have been the first to do so, around 1461. 
course of a century, these illustrations reached unprecedented perfection, culminating in the work of artists like Albrecht Dürer (1471-1528). These illustrations may have played a similar rôle among the more descriptive sciences as mathematical formalisation had in the subsequent century for the more theoretical ones. Famous examples of works full of important and artistically outstanding illustrations are Fuchs's Historia stirpium (1542), Vesalius' De humani corporis fabrica (1543), Agricola's De re metallica (1556), or Gesner's Historia animalium (15511558). Such illustrations, based on minute observation, may be viewed as the central scientific advance in many of these books, thus also diminishing the importance of the language used in the text. ${ }^{52}$ Some contemporary authors noticed this as well; according to Tommaso Campanella, ${ }^{53}$ learning the sciences through images becomes much faster and easier. In his utopian state, the inhabitants depict the following sciences in images on their six temple walls: geometry and geography, mineralogy and botany, animals, and the inventors of the sciences, including prophets.

\$9 Taken together, these factors had the result of replacing Latin as the sole carrier of Western European science. It was certainly political reasons (especially French nationalism) that weighed most heavily, while formalisation and illustrations eased the task of conveying scientific insights, which had become less dependent on natural language. It was of great importance to the success of the Scientific Revolution that the vocabulary was already available in Latin. As Crombie (1994: 1:12) puts it:

They [early modern natural philosophers] came to express causality in the language not of subject and predicate but of algebraic functions, and they devised a new Latin terminology to express such fundamental quantities as velocity, acceleration, instantaneous velocity and so on. These quantities were defined in the 14th c. in Paris and Oxford and their terminology was used by Galileo and Newton.

Once this was available, science's transplantation into vernacular languages became much easier. But it is hard to imagine such an international phenomenon as the Scientific Revolution if Latin had lost its central positions a few centuries earlier.

Quite in general, it is usually power politics that decide what language is used in a cultural space: after the Arab conquests, Persian, Syriac, Indian, Spanish, and Jewish authors began to write Arabic, which thus became an important

52 See Rossi (1997: 60-67).

53 Scientiarum faciles per picturam disciplinae (Civitas solis, ed. Tornitore, p. 12). 
international language, also for science. Today, authors from around the globe write in English if they wish to be read internationally. Nationalism in Europe had the disadvantageous consequence that one language of science was replaced with at least three that had to be learned by scientists. But this was an accident: the French in the eighteenth century obviously strove to replace Latin with French alone. Toward the end of the twentieth century, it seemed that the Germans (who lost the War) and even the French were being coerced into using English, which finished the struggle for hegemony as winner. With the likely demise of US world domination, other languages may take over from English as the main language of science, although this is not necessarily so: 'fixed' languages, such as Sumerian, Sanskrit, Greek, and Latin, were used for many centuries without a hegemonic power backing them. That science, with its own formal structures and the importance of illustrations, is today less dependent on language will ease the process of changing from English to its successor(s). Of course, a change of the language of science always produces heavy losses in general knowledge (only what is translated remains available, as we have seen in chap. 9 above). Machine translation may mitigate this problem in the future. ${ }^{54}$ The next chapter will present a few examples of niches in which Latin survived longer, in some cases until today.

\section{Excursus: Artificial languages}

\$10 The strong interventions in lexicon and syntax in the making of scientific scholastic Latin and then in the adaptation of the vernacular languages makes one wonder about their connection to artificially constructed languages. Besides technical languages that develop naturally, such as for instance the jargon of public administration (Verwaltungssprache) already in the Early Middle Ages, ${ }^{55}$ quite a universal tendency for some individuals to 'improve' their language or to invent an altogether new one for a variety of reasons can be observed. ${ }^{56}$ We have already met Lullus, who extended Latin by very free suffixation (chap. 12 §5). Among altogether newly created languages, a priori ones are distinguished from a posteriori ones. The latter 'improve' existing languages; the former are invented from scratch and presuppose an 'ontology' (a full classification of reality). Some

54 The German project DeepL (https://www.deepl.com) already (2020) produces surprisingly good translations of German science and philosophy into English.

55 See Norberg (1975: 89): its main characteristics were 'Klarheit und Objektivität' ('clarity and objectivity'). Its relation to scientific language would be interesting to study.

56 A systematic overview of such reasons can be found in in Bausani (1974). More narrowly on the early modern attempts, see Eco (1993). 
of the former, such as George Dalgarno's Ars signorum, ${ }^{57}$ could be very mathematical and logically structured, reminding us of Galileo's idea that mathematics is the language of God (see chap. $13 \S 4$ above). The fact that this approach depended very heavily on the languages known to the author, the structure of which was inevitably based on what has been called Standard Average European, ${ }^{58}$ and the ontology used depended on the European Begriffsgemeinschaft (see chap. 1 \$10 above), makes these a priori languages look rather naïve today. The silent consensus today seems to be that no generally human ontology for the entirety of reality accessible to mankind exists.

The fact that the question of a universal language, or at least a universal language of erudition and science, becomes especially prominent in the second half of the seventeenth century is an indicator that the rôle of Latin for exactly this purpose had become less a matter of course. The first important attempts were partly still written in Latin, such as those by Dalgarno or Johann Joachim Becher, ${ }^{59}$ and partly in vernaculars, especially English: John Wilkins ${ }^{60}$ or Francis Lodwick. ${ }^{61}$ Above (chap. $1 \S 4$ ), it was seen that some authors, especially of the eighteenth and nineteenth centuries, saw 'purified', hyper-classical Latin as the perfect and universally usable language. These 'antibarbarus' authors must have known that they were fighting a losing battle. Their approach will be discussed further below (chap. 16 \$1). Many of the later proposed artificial languages are still largely based on Latin (such as Esperanto, from 1887), ${ }^{62}$ or are even conscious attempts to 'improve' Latin through simplifying language engineering, such as Giuseppe Peano's Latino sine flectione (from 1915). The idea that the morphology of a universal language should be as simple as possible is common to many such attempts, quite missing the point that vocabulary is usually the most time-consuming part of language acquisition. The natural development of languages with little or no morphology is to become highly idiomatic (as English or Chinese have),

57 In full Ars signorum, vulgo character universalis et lingua philosophica (Londini: Hayes, 1661). Its basic logic is explained by Bausani (1974: 105-106).

58 See Haspelmath (2001); the term comes from Whorf (1944: 200). Further examples of shared features in Job (2005). Many common features can be observed in Western European languages (articles, syntax, relative clauses, parts of the vocabulary's structure) that are shared not so much with Latin but among all peoples who were in contact with Charlemagne's empire: Romance, Germanic languages, to some extent also Slavonic ones, Finno-Ugric ones, Modern Greek. The term Charlemagne Sprachbund is sometimes used.

59 Character pro notitia linguarum universali (Francofurti: Joh. Wilh. Ammon, 1661).

60 An Essay towards a Real Character, and a Philosophical Language (London: Gellibrand, 1668).

61 The Ground-Work, Or Foundation Laid, (or so intended) For the Framing of a New Perfect Language (London: n.p., 1652).

62 See Libert (2004). 
which hardly makes them easier to learn and use. Besides, Latin-based languages are of little help for people who do not already speak a Romance language. The topic of artificial languages seems to have rather cooled down in the twenty-first century, with the exception of programming languages, which have a much more restricted scope. 